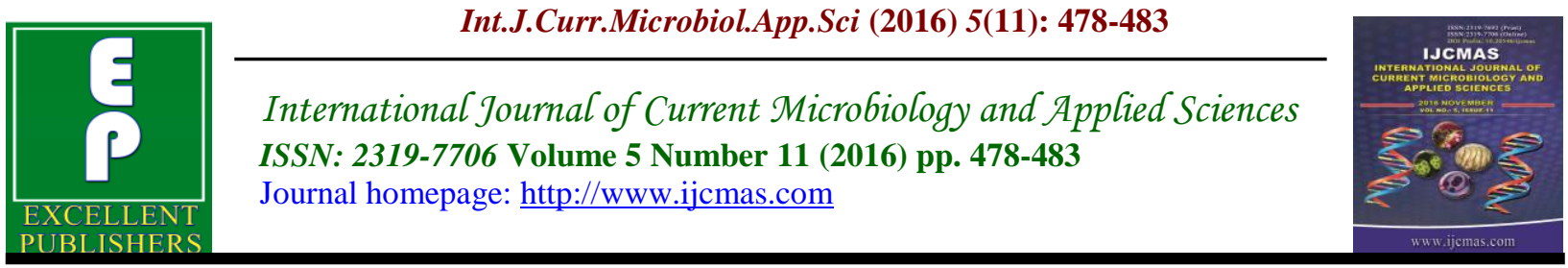

Original Research Article

http://dx.doi.org/10.20546/ijcmas.2016.511.055

\title{
Anticancer Activity Evaluation and Some Indian Medicinal Plants from Amarkantak Mekal Plateau Madhya Pradesh, India
}

\author{
Jitendra Malviya* and Vaibhavi Joshi \\ Department of Biotechnology, SIT College Sidhi, Madhya Pradesh, India \\ *Corresponding author
}

\section{A B S T R A C T}

Keywords

Anticancer, Medicinal Plants, Tumours, MTT assay, MCF-7, HT-29.

\section{Article Info}

Accepted:

23 October 2016

Available Online:

10 November 2016
Cancer is a major public health burden in both developed and developing countries. Anticancer activity is the effect of natural and synthetic or biological and chemical agents to reverse, suppress or prevent carcinogenic progression. Several synthetic agents are used to cure the disease but they have their toxicity and hence the research is going on to investigate the plant derived chemotherapeutic agents. Therefore an attempt has been made to review different invitro and in vivo methods for estimating anticancer properties of natural products from medicinal plants. In this research, anticancer medicinal plants of Indian origin belonging to families are reported along with detailed information regarding part used, extract used, type of the model used, types of tested cancer cell lines, etc. These plants continue to be used against various types of tumours such as sarcoma, lymphoma, carcinoma and leukemia. All these plants are potential candidates for in vivo studies since they are showing good in vitro anticancer activity.

\section{Introduction}

Cancer is one of the most severe health problems in both developing and developed countries, worldwide. Among the most common (lung, stomach, colorectal, liver, breast) types of cancers, lung cancer has continued to be the most common cancer diagnosed in men and breast cancer is the most common cancer diagnosed in women. An estimated 12.7 million people were diagnosed with cancer across the world in 2008, and 7.6 million people died from the cancer during the same year (Cancerstats Cancer Worldwide, 2011). Lung cancer, breast cancer, colorectal cancer and stomach cancer accounted for two-fifths of the total cases of cancers diagnosed worldwide
(Cancerstats Cancer Worldwide, 2011). More than $70 \%$ of all cancer deaths occurred in low- and middle-income countries. Deaths due to cancer are projected to continuously increase and it has been estimated that there will be 11.5 million deaths in the year 2030 (Russo Piovano Lombardo et al., 2007) and 27 million new cancer cases and 17.5 million cancer deaths are projected to occur in the world by 2050 (Douglas Kinghorn 2015 and Xiaoli Xu et al., 2016). More than $30 \%$ of cancers are caused by modifiable behavioral and environmental risk factors, including tobacco and alcohol use, dietary factors, insufficient regular consumption of fruit and 
vegetable, overweight and obesity, physical inactivity, chronic infections from Helicobacter pylori, hepatitis B virus (HBV), hepatitis C virus (HCV) and some types of human papilloma virus (HPV), environmental and occupational risks including exposure to ionizing and nonionizing.

Ayurveda, a traditional Indian medical practice using plant drugs has been successful from very early times in using these natural drugs and preventing or suppressing various tumours with different lines of treatment (Balachandran Govindarajan, 2005). In India, people of different ethnic groups inhabiting various terrains, possess their own distinct culture, religious rites, food habit and a rich knowledge of traditional medicine (Parinitha Srinivasa Shivanna, 2005). They practice herbal medicine to cure a variety of diseases. Natural products, especially plants have been used in the treatment of various diseases for thousands of years. Terrestrial plants have been used as medicines in Egypt, China, India and Greece from ancient times and an impressive number of modern drugs have been developed from them. Conventional treatment of cancer includes interventions such as psychosocial support, surgery, radiotherapy and chemotherapy (Kamboj, 2000). Currently, the most commonly use cancer chemotherapy includes mainly alkylating agents, antimetabolites, antitumor antibiotics, platinum analogs and natural anticancer agents (Rahman et al., 2014). However, due to the increasing rate of mortality associated with cancer and adverse or toxic side effects of cancer chemotherapy and radiation therapy, discovery of new anticancer agents derived from nature, especially plants, is currently under investigation. Screening of medicinal plants as a source of anticancer agents was started in the 1950s, with the discovery and development of vinca alkaloids, vinblastine and vincristine and the isolation of the cytotoxic podophyllotoxins (World Health Organization, 2010).

The cool temperate climate of Amarkantak, chhindwara and Panchmari Madhya Pradesh India supports the growth of an enormous number of plant species which are important sources of unique phytochemicals having anticancer properties (Table 01). In this chapter, selected medicinal plants grown in the cool climate of Amarkantak chhindwara (Patalkot) and Panchmari are discussed. The major bioactive phytochemicals and their mechanisms of action are also reviewed. Rubia cordifolia is a flowering plant with red rhizomatous base and roots, a member of Rubiaceae family, distributed in hilly tracts of India (Devi Priya, 2012). It has been reported in literature that the powdered dried roots and fruits have been tested for the treatment of skin diseases and disorders of spleen and its preparations are prescribed for treatment of major burns, bone fractures and dysentery and it is considered as tonic, antitussive and useful in chronic low fevers (Dev, 2006). This plant has many pharmacological properties like blood purifier activity, anticancer, astringent, antidysentric, antiseptic, antirheumatic, hepatoprotective etc. (Jong Keun Son et al., 2006). R. cordifolia is reported to be active against a diversified panel of cancer cell lines, such as P388, L1210, L5178Y,B16 melanoma, Lewis lung carcinoma, and sarcoma- 180 (Sankara Aditya, 2013). The roots of Rubia cordifolia L showed strong cytotoxicity against HT-29 and MCF-7 cell lines, and DNA topoisomerase I and II inhibitory activities (Chyuan-Chuan Wu, 2013). The adverse effects of oxidative stress on human health have become a serious issue. The World Health Organization (WHO) has estimated 
that $80 \%$ of the earth's inhabitants rely on traditional medicine for their primary health care needs, and most of this therapy involves the use of plant extracts and their active components. Medicinal plants have great antioxidant potential which is due to their contents of variable phyto constituents. A large number of experiments have been carried out concerning the antioxidant activity of several plant extracts and powders (Marzouk, 2006).

The results of these experiments reveal that, the activity is due to several secondary metabolites especially (Mbaveng et al., 2011). e.g., phenolic compounds (tannins, flavonoids, anthrocyanins, chalcones, xanthones, liganans, depsides, and depsidones), terpenes (sesquterpens and diterpines), alkaloids, and organic sulfur compounds (Malviya Jitendra, 2012; Rupesh Kapale. 2013 and Ramesh Kumar Ahirwar and Kumud Sandya, 2015).

\section{Materials and Methods}

\section{Collection of plant material}

Colocasia esculenta, Costus speciosus, Curcuma aromatic, Solanum nigrum, Swertia angustifolia Buch-Ham, Rubia Cordifolia plants were collected from and surrounding areas. The leaves were shade dried and then dried at $70 \circ \mathrm{C}$ in hot air oven. The dried leaves were then ground to powder using mortar and pestle. The powder is stored in airtight closed bottles.

\section{Preparation of plant extracts}

The shade dried $(100 \mathrm{~g})$ powder of each plant material were filled separately in the thimble and extracted with methanol using a Soxhlet extractor followed by distillation and evaporation. The plant powder is placed in a cellulose thimble in an extraction chamber, which is placed on top of a collecting flask beneath a reflux condenser. Methanol is added to the flask and the set up is heated under reflux. When a certain level of condensed solvent has accumulated in the thimble, it is siphoned into the flask beneath. Nearly 15 cycles are repeated for 72 hours for all the plant species. After extraction the solvent is removed by rotary evaporator, yielding the extracted compound. The nonsoluble portion of the extracted solid remains in the thimble, and is usually discarded.

\section{MTT assay}

Sensitivity of MCF-7 and HT-29 cells to Colocasia esculenta, Costus speciosus, Curcuma aromatic, Solanum nigrum, Swertia angustifolia Buch-Ham, Rubia Cordifolia was determined individually by the MTT colorimetric assay.Cells were seeded in a flat-bottomed 96-well plate and incubated for $24 \mathrm{~h}$ at $37^{\circ} \mathrm{C}$ and in $5 \% \mathrm{CO} 2$. Both cell lines were exposed to all three plant species mentioned above.

The solvent DMSO treated cells served as control. Cells were then treated with MTT reagent $(20 \mu \mathrm{l} /$ well $)$ for $4 \mathrm{~h}$ at $37^{\circ} \mathrm{C}$ and then DMSO $(200 \mu \mathrm{l})$ was added to each well to dissolve the formazan crystals. The optical density (OD) was recorded at $492 \mathrm{~nm}$ in a microplate reader. Percentage of residual cell viability was determined as [1-(OD of treated cells/OD of control cells) $] \times 100$.

\section{Results and Discussion}

Screening of methanolic extracts of Colocasia esculenta, Costus speciosus, Curcuma aromatic, Solanum nigrum, Swertia angustifolia Buch-Ham, Rubia Cordifolia resulted in moderate anticancer activities against MCF-7 and HT-29 cell lines. 
Table.1 List of Indian medicinal plants, their family, part used, solvents used for extraction and assay employed for anticancer studies.

\begin{tabular}{|c|c|c|c|c|}
\hline 1. & $\begin{array}{l}\text { Colocasia esculenta } \\
\text { (Linn.) Schott. Family } \\
\text { Araceae Local Name } \\
\text { Ghuia, Ruia }\end{array}$ & Herbs & Tuber & $\begin{array}{l}\text { Tuber is used to treat constipation, stomatitis, } \\
\text { hemorrhoids, cancer, and general weakness. }\end{array}$ \\
\hline 2. & $\begin{array}{l}\text { Costus speciosus (Koenig } \\
\text { ex Retz.) j.E.Smith. } \\
\text { Family: Zingiberaceae } \\
\text { Local Name me } \\
\text { Kebu, Kevu }\end{array}$ & $\begin{array}{l}\text { A perennial } \\
1 \text { meter in } \\
\text { height }\end{array}$ & Rhizome & $\begin{array}{l}\text { Plant pacifies vitiated kapha, pitta, burning } \\
\text { sensation, constipation, intestinal worms, skin } \\
\text { diseases, fever, and bronchitis. Plant } \\
\text { possesses anti-cancerous activity }\end{array}$ \\
\hline 3. & $\begin{array}{l}\text { Curcuma aromatic } \\
\text { Salisb. Family } \\
\text { Zingiberaceae } \\
\text { (Ginger family)Local } \\
\text { Name Jangli haldi } \\
\end{array}$ & $\begin{array}{l}\text { Under } \\
\text { ground } \\
\text { rhizomes }\end{array}$ & Tuber & $\begin{array}{l}\text { Wild turmeric is recognized as a medical herb } \\
\text { with strong antibiotic properties. It is believed } \\
\text { to play a role in preventing and curing cancer } \\
\text { in medicine. }\end{array}$ \\
\hline 4. & $\begin{array}{l}\text { Solanum nigrum Linn. } \\
\text { Family Solanaceae } \\
\text { Local Name } \\
\text { Makoi }\end{array}$ & herb & $\begin{array}{l}\text { Whole } \\
\text { plant }\end{array}$ & $\begin{array}{l}\text { Plant pacifies vitiated thridosas, swellings, } \\
\text { cough, asthma, arthritis, inflammation and } \\
\text { skin diseases, plant is a proven anti cancerous } \\
\text { drug. }\end{array}$ \\
\hline 5. & $\begin{array}{l}\text { Swertia angustifolia } \\
\text { Buch-Ham ex } \\
\text { D.Don.Family } \\
\text { Gentianaceae Local } \\
\text { Name Pahari chirayata } \\
\end{array}$ & Herbs & Leaves & $\begin{array}{l}\text { Its leaves are used to treat fever, abdominal } \\
\text { disorders, nausea, indigestion, constipation, } \\
\text { Dyspepsia, Skin disease, cancer and liver. }\end{array}$ \\
\hline 6. & $\begin{array}{l}\text { Rubia cordifolia Lin. } \\
\text { Family : Rubiaceae } \\
\text { Local Name } \\
\text { :Majith }\end{array}$ & Climbing & Leaves & $\begin{array}{l}\text { Plant pacifies vitiated pitta, rakta, kapha, } \\
\text { Jauindice neurogenicpain, skin diseases, } \\
\text { diabetes, Bleeding disorders, and erysipelas } \\
\text { and anticancer. It increases body power and } \\
\text { anti toxic in nature. }\end{array}$ \\
\hline
\end{tabular}

Table.2 Percent cell inhibition of plant extracts on MCF-7 cell line.

\begin{tabular}{|c|c|c|c|c|c|c|}
\hline \multirow{2}{*}{$\begin{array}{l}\text { Conc. } \\
(\mu \mathrm{g} / \mathrm{ml})\end{array}$} & \multicolumn{6}{|c|}{$\%$ cell inhibition } \\
\hline & $\begin{array}{l}\text { Colocasia } \\
\text { esculenta }\end{array}$ & $\begin{array}{l}\text { Costus } \\
\text { speciosus }\end{array}$ & $\begin{array}{l}\text { Curcuma } \\
\text { aromatic }\end{array}$ & $\begin{array}{l}\text { Solanum } \\
\text { nigrum }\end{array}$ & $\begin{array}{l}\text { Swertia } \\
\text { angustifolia } \\
\text { Buch-Ham }\end{array}$ & $\begin{array}{l}\text { Rubia } \\
\text { Cordifolia }\end{array}$ \\
\hline 15 & 5.05 & 10.07 & 4.53 & 4.04 & 6.25 & 4.05 \\
\hline 20 & 14.05 & 34.03 & 25.75 & 17.05 & 18.25 & 16.56 \\
\hline 50 & 27.00 & 66.41 & 30.23 & 46.24 & 27.65 & 28.66 \\
\hline 100 & 34.58 & 80.02 & 33.08 & 64.33 & 38.00 & 36.66 \\
\hline 200 & 50.02 & 57.06 & 50.00 & 19.46 & 55.00 & 54.22 \\
\hline
\end{tabular}


Table.3 Percent cell inhibition of plant extracts on HT-29 cell line.

\begin{tabular}{|c|c|c|c|c|c|c|}
\hline \multirow{2}{*}{$\begin{array}{l}\text { Conc. } \\
(\mu \mathrm{g} / \mathrm{ml})\end{array}$} & \multicolumn{6}{|c|}{$\%$ cell inhibition } \\
\hline & $\begin{array}{l}\text { Colocasia } \\
\text { esculenta }\end{array}$ & $\begin{array}{l}\text { Costus } \\
\text { speciosus }\end{array}$ & $\begin{array}{l}\text { Curcuma } \\
\text { aromatic }\end{array}$ & $\begin{array}{l}\text { Solanum } \\
\text { nigrum }\end{array}$ & $\begin{array}{l}\text { Swertia } \\
\text { angustifolia } \\
\text { Buch-Ham }\end{array}$ & $\begin{array}{l}\text { Rubia } \\
\text { Cordifolia }\end{array}$ \\
\hline 15 & 4.05 & 6.07 & 4.53 & 3.04 & 4.25 & 2.05 \\
\hline 20 & 12.05 & 14.03 & 15.75 & 07.05 & 08.25 & 16.56 \\
\hline 50 & 22.00 & 26.41 & 20.23 & 16.24 & 17.65 & 18.66 \\
\hline 100 & 24.58 & 30.02 & 23.08 & 24.33 & 28.00 & 26.66 \\
\hline 200 & 30.02 & 47.06 & 25.00 & 29.46 & 35.00 & 30.22 \\
\hline
\end{tabular}

The inhibitory properties of these extracts are compared with standard tamoxifen for MCF-7 cell line for HT-29 cell line (Tables 2 and 3 ) respectively. The Percentage cancer cell inhibition profiles were found to be concentration dependent (Figures 2 and 3). The maximum concentration $(\mu \mathrm{g} / \mathrm{ml})$ used in the study was $200 \mu \mathrm{g} / \mathrm{ml}$. Following results were obtained when anticancer activities of three plants were studied. In this article, some anticancer medicinal plants of Indian origin have been presented. These medicinal plants possess good antioxidant properties, leading to anticancer activities.

The aim of this study was to give an overview on the progress of anticancer medicinal plant research around the continental India, focusing on the most important findings of scientists in this field. We have tried to explore the discovered plants components with proved anticancer activity both in vitro and in vivo. India is one of the most promising regions for discovering novel biologically-active substances from its flora. More efforts are needed to explore potent anticancer plants from the mother earth and save humans around the world from cancer.

\section{References}

Balachandran, P., Govindarajan, R. 2005. Cancer- an ayurvedic perspective. Pharmacol. Res., 51: 19-30.
Cancer Research UK and International Agency for Research on Cancer, Cancerstats, Cancer Worldwide. 2011. Chyuan-Chuan $\mathrm{Wu}$, Yi-Ching Li , Ying-Ren Wang, Tsai-Kun Li and Nei-Li Chan. 2013. On the structural basis and design guidelines for type II topoisomerasetargeting anticancer drugs Oxford, J. Sci. Mathematics Nucleic Acids Res., Volume 41, Issue 22 Pp. 10630-10640 Nucl. Acids Res. (2013) 41 (22):1063010640.doi: 10.1093/nar/gkt828

Dev, S. 2006. A selection of Prime Ayurvedic Plant Drugs: Ancient Modern concordance. Anamaya Publishers, New Delhi, p377- 381

Devi Priya, M. and E.A. Siril. 2012. Pharmacognostic Studies on Indian Madder (Rubia Cordifolia L. J. Pharmacognosy and Phytochemistry, 5:113.

Douglas Kinghorn, A. 2015. Review of Anticancer Agents from Natural Products J. Nat. Prod., 78(9), pp 23152315.

DOI: 10.1021/acs.jnatprod.5b00617

Publication Date (Web): September 10, 2015

Jitendra Malviya, Vaibhavi Joshi, Kiran Singh. 2012. Antimicrobial activity of Some Ethno-medicinal Plants used by Baiga Tribes from Amarkantak, India, Advances in Life Science and Technol., www.iiste.org ISSN 2224- 


\section{1 (Paper) ISSN 2225-062X}

(Online) Vol 4.

Jong Keun Son, Ji Hyun Jung, Chong Soon

Lee, et al. 2006. DNA Topoisomerases

I and II Inhibition and Cytotoxicity of

Constituents from the Roots of Rubia cordifolia, Bull. Korean Chem. Soc., 27: 8.

Kamboj, V.P. 2000. Herbal Medicines. Curr. Sci., 78: 35-39.

Marzouk, M.S.A., Moharram, F.A., Mohamed, M.A., Gamal-Eldeen, A.M. and Aboutabl, E.A. 2006. Anticancer and antioxidant tannins from Pimenta dioica leaves. J. Biosci., 62: 526-536.

Mbaveng, A.T., Kuete, V., Mapunya, B.M., Beng, V.P., Nkengfack, A.E., Meyer, J.J. and Lall, N. 2011. Evaluation of four Cameroonian medicinal plants for anticancer, antigonorrheal and antireverse transcriptase activities. Environ. Toxicol. Pharmacol., 32: 162167.

Parinitha, M., Srinivasa, B.H., Shivanna, M.B. 2005. Medicinal plant wealth of local communities insome villages in Shimoga distinct of Karnataka. India J. Ethnopharmacol., 98: 307-312.

Rahman, H.S., Rasedee, A., Yeap, S.K., Othman, H.H., Chartrand, M.S., et al. 2014. Biomedical properties of a natural dietary plant metabolite, Zerumbone, in cancer therapy and chemoprevention trials. BioMed. Res., $1-20$.

Ramesh Kumar Ahirwar and Kumud Sandya. 2015. Documentation of some Threatened Ethnomedicinal Plants used by Tribes of Achanakmar-Amarkantak
Biosphere Reserve, Central India, Int. J. Curr. Microbiol. App. Sci., 4(8): 804811.

Rupesh Kapale. 2012. Ethnomedicinal Plants used by Baiga Tribals in Amarkantak Meikal forest of Madhya Pradesh (India) Bull. Environ. Pharmacology \& Life Sciences Volume 1, Issue 4, March 2012: $14 \quad-15$ Journal's URL: www.bepls.com Online ISSN 2277-1808 Original Article [Accepted 09 March 2012]

Russo, A., Piovano, M., Clericuzio, M., Lombardo, L., Tabasso, S., Chamy, M.C., Vidari, G., Cardile, V., VitaFinzi, P., Garbarino, J.A. 2006. Putrescine-1,4-dicinnamide from Pholiota spumosa (Basidiomycetes) inhibits cell growth of human prostate cancer cells. Phytomed., 14(2-3):18591.

Sankara Aditya, V.S.P.K., J. Naresh Kumar L. and Animisha Mokkapati. 2013. In vitro anti-cancer activities of few plant extracts against MCF-7 and HT-29 cell lines, Int. J. Pharma Sci., Vol. 3, No. 2 (2013): 185-188.

WHO. 1992. Quality Control Methods for Medicinal Plant Materials. World Health Organization, Geneva.

Xiaoli Xu, Yue Wu, Mingyang Hu, Xiang L, Congying Gu, Qidong You, Xiaojin Zh

ang. 2016. Structure-activity relationship of Garcinia xanthones analogues: Potent Hsp90 inhibitors with cytotoxicity and antiangiogenesis activity Bioorganic \& Medicinal Chemistry, 24(19): 4626-4635.

\section{How to cite this article:}

Jitendra Malviya and Vaibhavi Joshi. 2016. Anticancer Activity Evaluation and Some Indian Medicinal Plants from Amarkantak Mekal Plateau Madhya Pradesh, India. Int.J.Curr.Microbiol.App.Sci. 5(11): 478-483. doi: http://dx.doi.org/10.20546/ijcmas.2016.511.055 